\title{
Chemistry of two new Leprarioid lichens from Sri Lanka
}

\author{
Selvaluxmy Kathirgamanathar ${ }^{1}$, Anura Wickramasinghe ${ }^{1}$, Karunananda Bombuwela ${ }^{1}$, \\ Pat Wolseley ${ }^{2}$ and Veranja Karunaratne ${ }^{1 *}$ \\ 'Department of Chemistry, University of Peradeniya, Peradeniya \\ ${ }^{2}$ Department of Botany, British Natural History Museum, Cromwell Road, London SW75BD, U.K.
}

\begin{abstract}
The hexane and dichloromethane extracts of the lichen Leproloma sipmanianum, collected from Beragala, contained the compounds, atranorin 1, $\beta$-sitosterol 2, (+)-usnic acid 3, zeorin 4 and tritetracontylpentanoate 5 while the methanol extract furnished the triterpenoid $3 \beta$-acetoxyfern-9(11)-ene 6 . In addition to compounds $1-5$, the lichen powder yielded glyceryl trilinolate 7 and 3, 6-dimethyl-2-hydroxy-4-methoxybenzoic acid 8 . Chromatography of the lichen powder of Lepraria atrotomentosa led to the isolation of five compounds, including compounds 1-4 along with methyl- $\beta$-orcinolcarboxylate 9. (+)-Usnic acid exhibited potent antitermite activity against a common pest of tea at low elevations, Glyptotermes dilatatus. 3, 6-Dimethyl-2-hydroxy-4-methoxybenzoic acid 8 showed moderate larvicidal activity against the second instar larvae of Aedes aegypti.
\end{abstract}

Key words: Anti termite assay, atranorin, 3,6-dimethyl-2-hydroxy4-methoxybenzoic acid, glyceryl trilinolate, Lepraria atrotomentosa, Leproloma sipmanianum, lichen, methyl- $\beta$-orcinolcarboxylate, mosquito larvicidal assay, tritetracontylpentanoate, (+)-usnic acid,

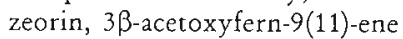

\section{INTRODUCTION}

Lichens are biologically distinct entities composed of an algal or cyanobacterial partner (photobiont) and a fungal partner (mycobiont) living in a symbiotic state. ${ }^{1}$ The mycobiont plays an important role in absorbing mineral nutrients and protects the lichen from exposure to intense sunlight and desiccation. The mycobiont, in turn, obtains sugars and in some cases organic nitrogen from the photosynthetic partner. ${ }^{2}$ Lichens synthesize a wide variety of metabolites with different structures and potential biological activities. These activities range from being poisonous (to insects, snails and nematodes) to antibiotic, antitumour, antiherbivore and growth and enzyme inhibitory. ${ }^{3}$ Lichens play a prominent role in air pollution studies because of their sensitivity to different gaseous pollutants, trace metals and radioactive elements. ${ }^{3}$

\section{METHODS AND MATERIALS}

General methods: Melting points were determined by using a Kofler hot stage apparatus and are uncorrected. UV absorptions were measured in a Shimadzu 1601 UV spectrophotometer. IR spectra were recorded on a Shimadzu 160 spectrophotometer on $\mathrm{KBr}$ pellets. Optical rotations were determined in a Bellingham-Stanley ADP 220 polarimeter. ${ }^{1} \mathrm{H} N M R,{ }^{13} \mathrm{C}$ NMR/ DEPT, HETCOR and HMBC spectra were recorded on a VARIAN $\left({ }^{1} \mathrm{H}\right.$ 300 and ${ }^{13} \mathrm{C} 75.45 \mathrm{MHz}$ ) in $\mathrm{CdCl}_{3}$ with TMS (tetramethylsilane) as the internal standard. Low and high resolution electron impact mass spectra were recorded on a Kratos/AEI MS-902 spectrometer detector. FAB (Fast Atom Bombardment) mass spectra were measured on a Varian Mat $\mathrm{CH} 4-\mathrm{B}$ spectrometer using 1-thioglycerol as the matrix. Silica gel used was Merck Kieselgel (230 - 400 mesh ASTM).

Collection, extraction andisolation: L. sipmanianum was collected from Beragala (Uva Province). Specimens were cleaned, airdried and ground to a fine powder $(100 \mathrm{~g})$, which then was sequentially extracted into hexane, dichloromethane and methanol using a bottle shaker at room temperature. The methanol extract $(10 \mathrm{~g})$ was subjected to Medium Pressure Liquid Chromatography (MPLC) (eluent: $\mathrm{CH}_{2} \mathrm{Cl}_{2}$ to $\mathrm{MeOH}$ ) to yield 12 fractions. The first two fractions upon further MPLC \{eluent: $\mathrm{CH}_{2} \mathrm{Cl}_{2}$ : hexane (1:4) $\mathrm{CH}_{2} \mathrm{Cl}_{2}$ \} gave $3 \beta$ acetoxyfern-9(11)-ene $6(68.7 \mathrm{mg})$ which was crystallized from $\mathrm{CH}_{2} \mathrm{Cl}_{2}$ while fractions 3 and 4 of the $\mathrm{CH}_{2} \mathrm{Cl}_{2}$ to $\mathrm{MeOH}$ MPLC yielded atranorin 1 (Figure 1). 
The lichen powder upon MPLC \{eluent: $\mathrm{CH}_{2} \mathrm{Cl}_{2}$ : hexane (1:39) to $\mathrm{MeOH}\}$ yielded 6 fractions. Fraction 2 upon gravity column chromatography $\left\{\right.$ (eluent: $\mathrm{CH}_{2} \mathrm{Cl}_{2}$ : hexane (1: 17)\} gave tritetracontylpentanoate $5(1 \mathrm{mg})$. Fraction 3 of the same column was subjected to further MPLC \{eluent: $\mathrm{CH}_{2} \mathrm{Cl}_{2}$ : hexane (1:9) to $\mathrm{CH}_{2} \mathrm{Cl}_{2}$ : hexane (3: 2)\} provided two compounds, namely atranorin 1 (238 $\mathrm{mg})$ and glyceryl trilinolate $7(6 \mathrm{mg})$; fraction 4 upon MPLC \{eluent: $\mathrm{CH}_{2} \mathrm{Cl}_{2}$ : hexane (1:9) to $\mathrm{CH}_{2} \mathrm{Cl}_{2}$ \} yielded b-sitosterol $2(1.6 \mathrm{mg})$; fraction 5 upon MPLC \{eluent: $\mathrm{CH}_{2} \mathrm{Cl}_{2}$ : hexane (1:9) to $\mathrm{CH}_{2} \mathrm{Cl}_{2}$ : hexane (3:2)\} furnished 3,6-dimethyl-2-hydroxy-4-methoxybenzoic acid $8(19 \mathrm{mg})$; fraction 6 upon MPLC \{eluent: $\mathrm{CH}_{2} \mathrm{Cl}_{2}$ to $\mathrm{MeOH}$ : $\left.\mathrm{CH}_{2} \mathrm{Cl}_{2}:(1: 19)\right\}$ yielded zeorin 4 (89 mg).

\section{L. atrotomentosa was collected from Ramboda (Central} Province). Specimens collected were cleaned, air-dried and ground into a fine powder. It was mixed with silica gel and subjected to direct MPLC \{eluent: $\mathrm{CH}_{2} \mathrm{Cl}_{2}$ : hexane (1:19) to $\mathrm{MeOH}$ \} to yield 5 fractions. Fraction 3 upon MPLC \{eluent: $\mathrm{CH}_{2} \mathrm{Cl}_{2}$ : hexane $(2: 3)$ to $\mathrm{CH}_{2} \mathrm{Cl}_{2}$ \} gave atranorin $1(63.7 \mathrm{mg})$ and b-sitosterol $2(1.2 \mathrm{mg})$. (+)-Usnic acid 3 (4 mg) was crystallized $\left(\mathrm{CH}_{2} \mathrm{Cl}_{2}\right)$ from fraction 4 . Fraction 5 upon repeated MPLC yielded methyl-b-orcinolcarboxylate $9(1.3 \mathrm{mg})$.

Tritetracontylpentanoate 5: Colourless powder;m.p. 196-198 ${ }^{\circ} \mathrm{C} ; \mathrm{IR}(\mathrm{KBr}) \gamma_{\min }\left(\mathrm{cm}^{-1}\right): 1730(\mathrm{~s}), 2950(\mathrm{~s}), 2850(\mathrm{~s}), 1455 ;{ }^{\prime} \mathrm{H}$ $\operatorname{NMR}\left(300 \mathrm{MHz}_{2}, \mathrm{CDCl}_{3}\right): \delta 0.84,0.88(6 \mathrm{H}$, overlapping $\mathrm{t}, J$ $5.1 \mathrm{~Hz}, \mathrm{Me}), 1.25\left(82 \mathrm{H}, \mathrm{bs}, \mathrm{CH}_{2}\right), 1.60\left(4 \mathrm{H}, \mathrm{m}, \mathrm{CH}_{2}\right), 2.30$ $\left(2 \mathrm{H}, \mathrm{t}, J=7.5 \mathrm{~Hz}, \mathrm{CH}_{2}\right), 4.05\left(2 \mathrm{H}, \mathrm{t}, J=10.5 \mathrm{~Hz}, \mathrm{CH}_{2} \mathrm{O}\right)$; EIMS $m / z 704,676,648,620,592,564,536,465,420,392$, $369,341,313,295,285,257,111,97,85,71,57$ (100), 54; HREIMS $\left(\mathrm{M}^{+}\right) \mathrm{m} / \mathrm{z} 704.7365$ (calcd. for $\mathrm{C}_{48} \mathrm{H}_{96} \mathrm{O}_{2}, 704.7403$ ).

Hydrolysis of tritetracontylpentanoate 5: Tritetracontylpentanoate $5(10 \mathrm{mg})$ was dissolved in THF (tetrahydrofuran), mixed with $10 \% \mathrm{NaOH}(3 \mathrm{ml})$ and stirred for two h. The reaction mixture was monitored by TLC (Thin Layer Chromotography) for the disappearance of the starting material. After the completion of the reaction, the mixture was acidified with dilute $\mathrm{HCl}$ until the $\mathrm{pH}$ of the solution was acidic. The solid obtained was filtered and the filtrate was extracted with $\mathrm{CH}_{2} \mathrm{Cl}_{2}(10 \mathrm{ml}$ x 3$)$. The $\mathrm{CH}_{2} \mathrm{Cl}_{2}$ was evaporated in a rotavapor and the resultant crude solid was used to obtain the ${ }^{1} \mathrm{HNMR}$ spectrum.

Tritetracontanol: Colourless solid; ${ }^{1} \mathrm{HNMR}\left(300 \mathrm{MHz}, \mathrm{CDCl}_{3}\right)$ : $\delta 0.84(3 \mathrm{H}, \mathrm{t}, J \sim 5.2 \mathrm{~Hz}, \mathrm{Me}), 1.25\left(82 \mathrm{H}, \mathrm{bs}, \mathrm{CH}_{2}\right)$ and 4.25 $\left(2 \mathrm{H}, t, J=10.3 \mathrm{~Hz}, \mathrm{CH}_{2} \mathrm{O}\right) .3 \beta$-acetoxyfern-9(11)-ene 6: Colourless scales; m.p. $242-244^{\circ} \mathrm{C}$ (lit. m.p. $\left.218-220^{\circ} \mathrm{C}\right)^{5}$; $[\alpha]_{0}{ }^{25.7}+75.0^{\circ}\left(\mathrm{CH}_{2} \mathrm{Cl}_{2}\right) ; 1^{1} \mathrm{HNMR}\left(300 \mathrm{MHz}, \mathrm{CDCl}_{3}\right): 80.82$ (3H, s, Me-28), 0.86 (3H, s, Me-30), 0.87 (3H, s, Me-24), 0.90 (3H, s, Me-29), $0.95(3 \mathrm{H}, \mathrm{s}, \mathrm{Me}-27), 1.09$ (3H, s, Me-25), 1.32 (2H, s, H-16), 1.44 (2H, s, H-7), 1.46 (1H, s, H-18), 1.62
(2H, s, H-2), $1.64(2 \mathrm{H}, \mathrm{s}, \mathrm{H}-6), 1.89(1 \mathrm{H}, \mathrm{d}, J=3 \mathrm{~Hz}, \mathrm{H}-12)$, $1.94(1 \mathrm{H}, \mathrm{d}, J=3 \mathrm{~Hz}, \mathrm{H}-12), 2.02(1 \mathrm{H}, \mathrm{m}, \mathrm{H}-8), 2.03(3 \mathrm{H}$, s, -OCOMe), $4.45(1 \mathrm{H}, \mathrm{dd}, J=6.9,9.7 \mathrm{~Hz}, \mathrm{H}-3), 5.53(1 \mathrm{H}$, $\mathrm{dd}, J=3.00,8.25 \mathrm{~Hz}, \mathrm{H}-11)$ and $1.20-1.70(11 \mathrm{H}) ;{ }^{13} \mathrm{C}$ NMR (75.45 MHz, CDCl $)$ : C-1: 39.0, C-2: 23.4, C-3: 81.0, C-4: 37.9, C-5: 48.8, C-6: 18.7, C-7: 17.5, C-8: 41.2, C-9: 158.0, C-10:37.4, C-11: 116.9, C-12:37.4, C-13:37.7, C-14: 37.7, C-15: 28.8, C-16: 36.7, C-17: 48.8, C-18: 49.2, C-19: 21.4, C-20: 35.8, C-21: 55.7, C-22: 35.1, C-23: 33.3, C-24: 16.5, C-25: 25.9, C-26: 33.7, C-27: 15.4, C-28: 29.8, C-29: 29.9, C-30: 27.9, C-3-OCOMe: 21.4, C-3-OCOMe: 170.9; EIMS $m / z$ (rel. int. \%) 453, 344, 329, 269, 218, 204, 189, $175,161,147,135,121,107,95,84,79,69$ and $43(100)$; HREIMS $\left(\mathrm{M}^{+}\right)$at $\mathrm{m} / \mathrm{z} 468.3967$; calcd. for $\mathrm{C}_{32} \mathrm{H}_{52} \mathrm{O}_{2}$, 468.3969 .

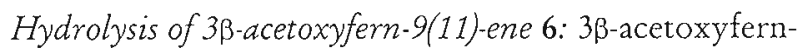
$9(11)$-ene $6(8 \mathrm{mg})$ was refluxed with $6 \%$ methanolic $\mathrm{KOH}(5 \mathrm{ml})$ for $4.5 \mathrm{~h}$. The product was diluted with water $(10 \mathrm{ml})$, extracted into ethyl acetate and dried with $\mathrm{MgSO}_{4}$. The solvent was removed and the crude product was crystallized from $\mathrm{CH}_{2} \mathrm{Cl}_{2}$ to obtain the alcohol 6' (7) $\mathrm{mg}$ ) as colourless scales.

Fern-9(11)-ene-33-ol 6': Colourless scales; m.p. $(274-276)^{\circ} \mathrm{C}$; $[\alpha]_{D}^{25.7}+83.3^{\circ}\left(\mathrm{CH}_{2} \mathrm{Cl}_{2}\right) ;{ }^{1} \mathrm{HNMR}\left(300 \mathrm{MHz}, \mathrm{CDCl}_{3}\right): \delta 0.80$ (3H, s, Me-28), 0.82 (3H, s, Me-30), 0.91 (3H, s, Me-24), 0.93 (3H, s, Me-29), 0.97 (3H, s, Me-27), 1.09 (3H, s, Me-25), 1.32 (2H, s, H-16), 1.59 (2H, s, H-2), $1.61(2 \mathrm{H}, \mathrm{s}, \mathrm{H}-6), 1.89$ (1H, d, $J \sim 2.7 \mathrm{~Hz}, \mathrm{H}-12), 1.94(1 \mathrm{H}, \mathrm{d}, J \sim 2.7 \mathrm{~Hz}, \mathrm{H}-12), 2.02$ $(1 \mathrm{H}, \mathrm{m}, \mathrm{H}-8), 3.19(1 \mathrm{H}, \mathrm{dd}, J=5.1,10.35 \mathrm{~Hz}, \mathrm{H}-3), 5.53$ $(1 \mathrm{H}, \mathrm{dd}, J=3,8.1 \mathrm{~Hz}, \mathrm{H}-11)$ and $1.20-1.70(14 \mathrm{H})$.

Atranorin 1: Colourless needles $\left(\mathrm{CH}_{2} \mathrm{Cl}_{2}\right)$; m.p. $195-196^{\circ} \mathrm{C}$ (lit. m.p. $196^{\circ} \mathrm{C}$ ). ${ }^{6}$

B-Sitosterol 2: Colourless needles $\left(\mathrm{CH}_{2} \mathrm{Cl}_{2}\right) ; \mathrm{m} \cdot \mathrm{p} \cdot 140-142^{\circ} \mathrm{C}$ (lit. m.p. $\left.140-141^{\circ} \mathrm{C}\right)$ ?

(+)-Usnic acid 3: Yellow prisms $\left(\mathrm{CH}_{2} \mathrm{Cl}_{2}\right) ;$ m.p. $203-204^{\circ} \mathrm{C}$ (lit. m.p. $\left.203^{\circ} \mathrm{C}\right) .^{8}$

Zeorin 4: Colourless needles $\left(\mathrm{CH}_{2} \mathrm{Cl}_{2}\right)$; m.p. $234-236^{\circ} \mathrm{C}$ (lit. m.p. $\left.236-242^{\circ} \mathrm{C}\right){ }^{9} ;{ }^{13} \mathrm{CNMR}(75.45 \mathrm{MHz}, \mathrm{CDCl}$ ): $\mathrm{C}-1: 40.3$, C-2: 18.5, C-3: 43.8, C-4:33.6, C-5: 61.1, C-6: 69.3, C-7: 45.6, C-8: 42.9, C-9: 49.4, C-10: 39.3, C-11:21.3, C-12: 23.9, C-13: 49.8, C-14: 41.6, C-15: 34.3, C-16: 21.9, C-17: 54.0, C-18: 44.0, C-19: 41.2, C-20: 26.6, C-21: 51.1, C-22: 73.9, C-23: 36.7, C-24: 22.1, C-25: 17.8, C-26: 18.9, C-27: 17.5, C-28: 16.1, C-29:28.7, C-30: 30.9 .

3, 6-Dimethyl-2-bydroxy-4-methoxybenzoic acid 8: Pale yellow needles; m.p. $195-196^{\circ} \mathrm{C}$ (lit. m.p. $\left.196^{\circ} \mathrm{C}\right) .{ }^{11}$

Metbyl-b-orcinolcarboxylate 9: Colourless needles $\left(\mathrm{CH}_{2} \mathrm{Cl}_{2}\right)$; m.p. $141-142^{\circ} \mathrm{C}$ (lit. m.p. $\left.140-141^{\circ} \mathrm{C}\right) .{ }^{12}$ 
Mosquito larvicidal assay ${ }^{13}$ : A laboratory culture of Aedes aegypti was used for the assay. Test solutions were prepared by dissolving crude extracts $(100 \mathrm{mg})$ or pure compounds $(1 \mathrm{mg})$ in acetone $(1 \mathrm{ml})$ and diluting with water up to $200 \mathrm{ml}$ (500 ppm for extracts; $10 \mathrm{ppm}$ for pure compounds). Polyethylene glycol $(120 \mu \mathrm{l})$ was added to homogenize the test solutions. These test solutions were used as treatments to screen against the second instar larvae of $A$. aegypti. Four replicates (five larvae in each beaker) were used for each treatment and the control contained all the ingredients except the lichen extract or the pure compound. The number of larvae moribund or dead was recorded after 24 and $48 \mathrm{~h}$.

Antitermite assay ${ }^{14}:$ Test compound $(10 \mathrm{mg})$ was dissolved in a minimum amount of $\mathrm{CH}_{2} \mathrm{Cl}_{2}$ and mixed with cellulose $(1.25 \mathrm{~g})$. The mixture was air dried under a current of warm air to evaporate the organic solvents. To the resultant mixture distilled water $(10 \mathrm{ml})$ was added and heated $\left(40-45^{\circ} \mathrm{C}\right)$ for $30 \mathrm{~min}$ to produce the slurry. An agar solution (1.0 g in $15 \mathrm{ml}$ of distilled water) was heated $\left(50-55^{\circ} \mathrm{C}\right)$ and mixed well with the cellulose/ compound slurry. The resultant mixture was compressed using a pellet block to prepare approximately five pellets (thickness: $1 \mathrm{~cm}$; diameter: $2.5 \mathrm{~cm}$ ). Pellets for the control experiment were prepared in the same manner without the test compound. Each pellet (five with the test compound and two without) was transferred to a petri dish and Glyptotermes dilatatus (10 each), which had been starved for $24 \mathrm{~h}$, were introduced. Mortality counts were recorded after $5 \mathrm{~d}$ from the start of the experiment and were continued for $30 \mathrm{~d}$. Kampferol was used as the positive control, which had $100 \%$ mortality in $23 \mathrm{~d}$ under the above conditions.

\section{RESULTS AND DISCUSSION}

L. sipmanianum described in this study was collected from an exposed and well-lit, siliceous bed-rock in Beragala (elevation $1077 \mathrm{~m}$ above sea-level), Central Province, Sri Lanka. It is a Leprose (loose powdery surface without a cortex) lichen. The thallus contains short distinct lobes with narrow upturned margins and deep cream in colour. L. sipmanianum has previously been reported from South Africa, Columbia and Brazi $1{ }^{15}$ and the report of it from Beragala is a new'record to the entire Asian region. ${ }^{16}$ Previously, we had reported on the presence of L. sipmanianum lichen compounds namely, atranorin 1, $\beta$-sitosterol 2, (+)-usnic acid 3, zeorin 4 and tritetracontylpentanoate 5 in the butterfly Talicada nyseus which is found in the vicinity of the lichen in Beragala. ${ }^{17}$ The butterfly, whose natural food source is Bryophyllum calycinum (Sinhala: akkapana; Tamil: malai-kalli), found in Beragala was very likely using the lichen as an alternative food source. Although moths of the family Arctiidae are known to be lichen feeders, that there are no records of a Lycaenid butterfly feeding on lichens, makes the association between $L$. sipmanianum and T. nyseus unique. In this study, we report on the isolation and structure elucidation of compounds $1-5$ and $3 \beta$-acetoyfern-9(11)-ene 6 from the methanol extract of $L$. sipmanianum, and glyceryl trilinolate 7 and 3, 6-dimethyl-2-hydroxy-4methoxybenzoic acid 8 directly from the lichen powder.

L. atrotomentosa was collected from partly shaded, overhung rock surfaces and on soil sheltered from rain in Ramboda (elevation $1700 \mathrm{~m}$ above sea-level), Central Province. ${ }^{17}$ It is a Crustose (crust like, thallus stretching over and firmly fixed to the substratum by the whole lower surface and generally lacking of rhizines) type lichen. The thallus is pale blue to grey in colour. There are no previous reports on the chemistry of this species. Chromatography of the lichen powder, in addition to compounds 1-4, yielded methyl-b-orcinolcarboxylate 9 .

The HREIMS of the compound 5 gave a peak at $\mathrm{m} /$ $z 704.7365$, suggesting that the molecular formula was $\mathrm{C}_{48} \mathrm{H}_{96} \mathrm{O}_{2}$. The IR spectrum showed a peak at $1730 \mathrm{~cm}^{-1}$ indicating that this molecule has an ester group which accounted for the one degree of unsaturation suggested by the molecular formula.

The ${ }^{1} \mathrm{H}$ NMR spectrum showed five peaks: a pair of overlapping triplets at $d 0.84$ and $0.88(6 \mathrm{H}, J \sim 5.1 \mathrm{~Hz}, \mathrm{H}-5)$ for the two terminal Me groups; an intense broad multiplet at $\mathrm{d} 1.25(82 \mathrm{H})$ due to a long éhain hydrocarbon units; a multiplet at $\mathrm{d} 1.60(4 \mathrm{H}, \mathrm{H}-3$ and $\mathrm{H}-4)$; a triplet at $\mathrm{d} 2.30(2 \mathrm{H}$, $J=7.5 \mathrm{~Hz}, \mathrm{H}-2)$ indicative of a $\mathrm{CH}_{2}$ group attached to an ester carbonyl group; the triplet at d $4.05(J=10.5 \mathrm{~Hz}, 2 \mathrm{H})$ represented a $\mathrm{CH}_{2} \mathrm{O}$ group which was attached to a $\mathrm{CH}_{2}$ group. The COSY (Correlation Spectroscopy) spectrum showed a correlation between the proton at $\mathrm{d} 4.05\left(\mathrm{CH}_{2} \mathrm{O}\right)$ and the methylene protons at $\mathrm{d} 1.25$. The proton at $\mathrm{d} 1.25$ further showed correlation between the methyl protons at $\mathrm{d} 0.84$. The foregoing data indicated that compound 5 was a long chain fatty acid ester with both the acid and the alcohol chains ending in a methyl group.

The mass spectral fragments at $m / z 57$ and $85\left(\mathrm{C}_{4} \mathrm{H}_{11}\right.$ and $\left.\mathrm{C}_{4} \mathrm{H}_{11} \mathrm{CO}\right)$ and 620 indicated a butyl group attached to the carbonyl group of an ester and $\mathrm{C}_{43}$ alcohol portion of the molecule, respectively. 
<smiles>CC(=O)c1c(C)cc(OC(=O)c2c(C)cc(O)c(C=O)c2O)c(C)c1O</smiles>

1

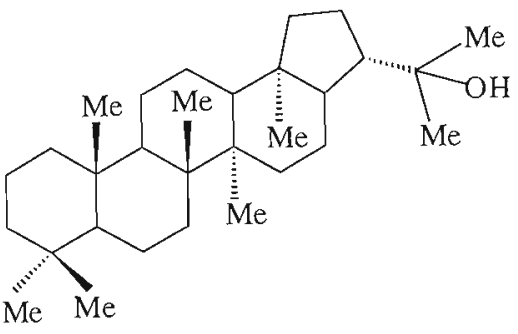

4

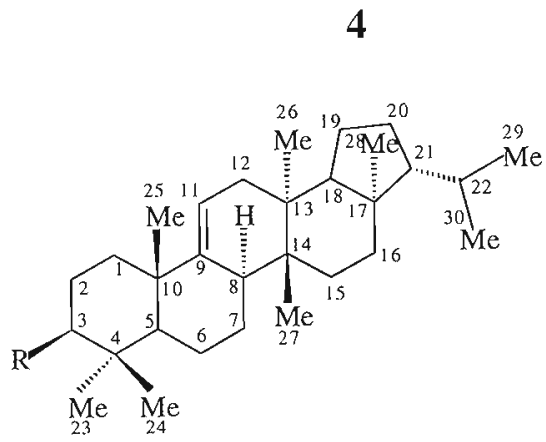

6: $\mathrm{R}=\mathrm{OAc} ;$ 6' $^{\prime} \mathrm{R}=\mathrm{OH}$<smiles>CC(=O)C1=C(O)C=C2Oc3c(C(C)=O)c(O)c(C)c(O)c3C2(C)C1=O</smiles><smiles>CC(C)COC(=O)CCC(C)[Te]</smiles>

5

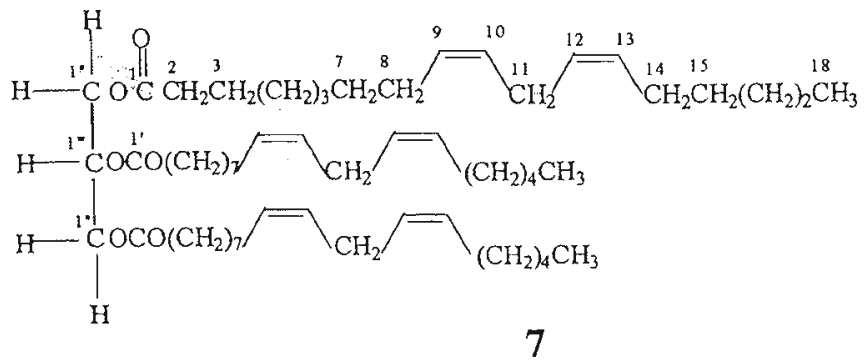<smiles>COc1cc(C)c(C(=O)O)c(O)c1C</smiles>

8<smiles>CC(=O)C1=C(C)C=C(O)C(C)C1O</smiles>

9

Figure 1: Compounds contained in the chemical extract of L.sipmanianum and L.atrotomentosa

Base hydrolysis of the compound gave tritetracontanol whose ${ }^{1} \mathrm{H}$ NMR spectrum showed a peak at $\mathrm{d} 4.05\left(\mathrm{CH}_{2}-\mathrm{O}\right)$, which was shifted to downfield compared to the same peak in the starting ester ( $\mathrm{d} 4.25)$ confirming that the $\mathrm{C}_{43}$ chain belongs to the alcoholic part of the ester. The ${ }^{1} \mathrm{H}$ NMR, COSY and the mass spectral data taken together to confirm this compound 5 as tritetracontylpentanoate. To the best of our knowledge this is a new natural product.
HREIMS of the compound 6 gave a molecular ion at 468.3967 suggesting an elemental composition of $\mathrm{C}_{32} \mathrm{H}_{52} \mathrm{O}_{2}$ which was confirmed by ${ }^{13} \mathrm{CNMR}$ (32 peaks) and DEP'T $\left(9 \times \mathrm{CH}_{3}, 9 \times \mathrm{CH}_{2}, 7 \times \mathrm{CH}\right.$ and 5 quarternary carbons) analysis.

The ${ }^{1} \mathrm{HNMR}$ spectrum of compound 6 indicated that it was a triterpenoid with oxygenation in ring $\mathrm{A}$ at C-3: it showed six methyl singlets at d $0.82(\mathrm{Me}-28), 0.86(\mathrm{Me}-$ 


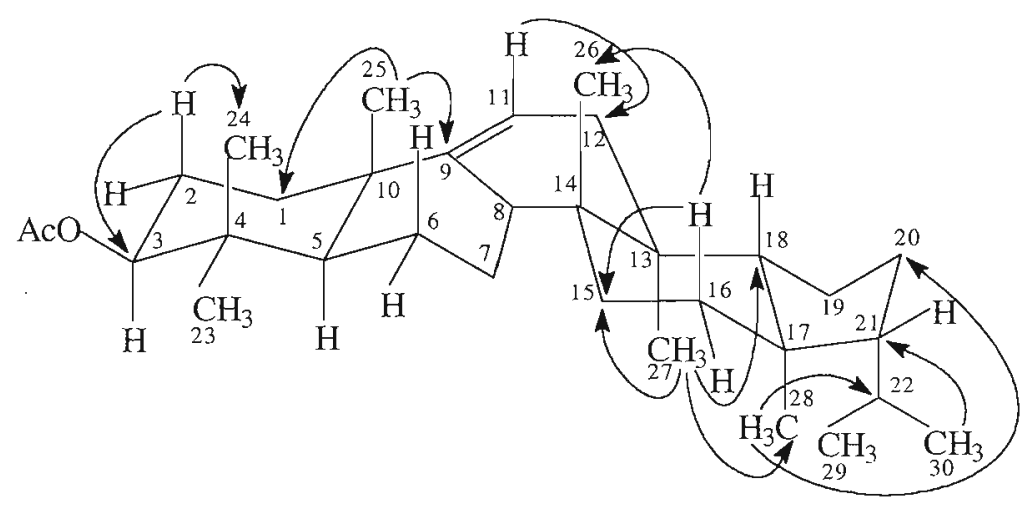

Figure 2: HMB Correlations of 3b-acetoxyfern-9(11)-ene 6.

30), $0.87(\mathrm{Me}-24), 0.90(\mathrm{Me}-29), 0.95(\mathrm{Me}-27)$ and $1.09(\mathrm{Me}-$ 25), a proton at $d 4.45$ (dd, $J=6.9,9.7 \mathrm{~Hz}, \mathrm{H}-3)$ under an acetoxy (OAc) group, an olefinic proton at $\mathrm{d} 5.53(\mathrm{dd}, J=$ $3,8.25 \mathrm{~Hz}, \mathrm{H}-11$ ) and a series of unresolved peaks extending from $\mathrm{d} 1.20$ to $1.70(11 \mathrm{H})$. The double doublet appearing at $\mathrm{d} 4.45(J=6.9,9.7 \mathrm{~Hz})$ due to an axial proton attached to $\mathrm{C}-3$ bearing the acetoxy group was consistent with an axial hydrogen, thus defining the acetoxy function as being equatorial.

The HETCOR identified correlations between the methylene protons $\mathrm{H}-2$ (d 1.62), $\mathrm{H}-6$ (1.64), $\mathrm{H}-7$ (1.44), $\mathrm{H}$ $12(1.89$ and 1.94$)$ and $\mathrm{H}-16(1.32)$ and the carbons at $\mathrm{d}^{13} \mathrm{C}$ 23.4 (C-2), 18.7 (C-6), 17.5 (C-7), 37.4 (C-12) and 36.7 (C16), respectively. The methine protons $\mathrm{H}-3(\mathrm{~d} 4.45)$ and $\mathrm{H}-18$ (1.46) coupled with the carbons at ${ }^{13} \mathrm{C} 81.0$ (C-3) and 49.2 (C-18), respectively while the olefinic proton $\mathrm{H}$ $11(\mathrm{~d} 5.53, \mathrm{dd}, J=3.00,8.25 \mathrm{~Hz}$ ) correlated with the carbon C-11 ( $\left.{ }^{13} \mathrm{Cd} 116.9\right)$.

HMBC showed correlations (Figure 2) between the methyl protons at $\mathrm{d} 0.87(\mathrm{H}-24), 1.09(\mathrm{H}-25), 0.95(\mathrm{H}-27)$, $0.82(\mathrm{H}-28)$ and $0.86(\mathrm{H}-30)$ and the carbons at ${ }^{13} \mathrm{C} \mathrm{d} 81.0$ (C3), [39.0 (C-1) and 158.0 (C-9)], [28.8 (C-15), 49.2 (C-18) and 29.8 (C-28)], [35.8 (C-20) and 35.1 (C-22)] and 55.7 (C-21), respectively. Furthermore, the methylene protons at ${ }^{1} \mathrm{H} \mathrm{d} 1.62$ $(\mathrm{H}-2), 1.64(\mathrm{H}-6), 1.89 \& 1.94(\mathrm{H}-12)$ and $1.32(\mathrm{H}-16)$ coupled with the carbons at ${ }^{13} \mathrm{C} \mathrm{d}[81.0(\mathrm{C}-3)$ and $16.5(\mathrm{C}-24)], 48.8$ (C-5), $116.9(\mathrm{C}-11)$ and $[28.8(\mathrm{C}-15)$ and $33.7(\mathrm{C}-26)]$, respectively. The olefinic proton at $\mathrm{d} 5.53$ (H-11) coupled with the carbon at $\mathrm{d} 37.4$ (C-12). The foregoing data established the position of the gem-dimethyl group at $\mathrm{C}-4$ with an acetoxy moiety at $\mathrm{C}-3$ and the $\mathrm{C}-25$ methyl is attached to an allylic quaternary carbon (C-10) adjacent to the double bond between C-9 and C-11. Furthermore, the methyls at C-26, C-27 and C28 with respect to the isopropyl group at $\mathrm{C}-21$ was discerned from the above data.
In the mass spectrum, a peak at $m / z 453$ was observed, due to the loss of Me group (15 mass units) from the $m / z 468\left(\mathrm{M}^{+}\right)$. The base peak at $\mathrm{m} / z 43(100)$ due to a $\mathrm{C}_{3} \mathrm{H}_{7}$ fragment confirmed the presence of isopropyl side chain.

In order to confirm the identity of this compound as $3 b$-acetoxyfern-9(11)-ene 6, the compound was hydrolysed with $6 \%$ methanolic $\mathrm{KOH}$. The ${ }^{1} \mathrm{H}$ NMR spectrum of the crude hydrolysed product fern-9(11)-ene3b-ol 6' showed six singlets at d $0.80(\mathrm{Me}-28), 0.82(\mathrm{Me}-$ 30), 0.91(Me-24), 0.93 (Me-29), 0.97(Me-27), 1.09 (Me-25) for the methyl groups, a carbinol methine proton at $\mathrm{d}$ $3.19(\mathrm{dd}, J=5.1,10.35 \mathrm{~Hz}, \mathrm{H}-3)$, an olefinic proton at $\mathrm{d}$ $5.53(\mathrm{dd}, J=3,8.1 \mathrm{~Hz}, \mathrm{H}-11)$ and a series of unresolved peaks from d 1.20 to $1.70(14 \mathrm{H})$. When the 'HNMR data for the two compounds $3 b$-acetoxyfern-9(11)-ene 6 and fern-9(11)-ene-3b-ol 6' were compared, the multiplicity and the chemical shift value for the olefinic proton was unchanged while the signal for the carbinol methine proton at C-3 moved upfield from d 4.45 to 3.19 (reported value $d 3.20$ ). The ${ }^{1} \mathrm{H}$ NMR spectral data of this compogund was identical to those reported for fern-9(11)ene- $3 b$-ol..$^{5}$ Thus, compound 6 was confirmed as $3 b$ acetoxyfern-9(11)-ene. ${ }^{5} 3 b$-Acetoxyfern-9(11)-ene 6 and its alcohol have been previously isolated from the plant Rhododendron macrocepalum but this is the first report of compound 6 (containing oxygenation at C-3) from a lichen. ${ }^{6}$ However, in the related fern-9(11)-ene-ols isolated from lichens, hydroxyl functionality occurs at C-12 or C-19. ${ }^{4}$

Spectral data ( ${ }^{1} \mathrm{HNMR},{ }^{13} \mathrm{CNMR}$ and mass) and physical data (m.p., TLC and co-TLC) were used in the identification of atranorin 1, b-sitosterol 2, (+)-usnic acid 3, zeorin 4, glyceryl trilinolate 7,3,6-dimethyl-2-hydroxy-4-methoxybenzoic acid 8 and methyl-b-orcinolcarboxylate 9 . 
3,6-Dimethyl-2-hydroxy-4-methoxybenzoic acid 8 at $10 \mathrm{ppm}$ showed moderate mosquito larvicidal activity ( $90 \%$ moribund after 24 hours) against the second instar larvae of Aedes aegypti, which is a major vector of dengue fever. The well-known antimicrobial compound known as (+)-usnic acid 4 showed significant antitermite activity ( $80 \%$ mortality at $10 \mathrm{mg}$ ) against Glyptotermes dilatatus, which is a major live-wood attacking tea-termite at low elevations.

\section{Acknowledgement}

Authors thank the National Science Foundation, Sri Lanka and IFS, Sweden and OPWC, Netherlands for financial assistance.

\section{References}

1. Nash T. H. III. (1996). Lichen biology. Cambridge Universicy Press.

2. Hale M. E. (1983). The biology of lichens. Edward Arnold, London.

3. Huneck S. (1999). The significance of lichens and their metabolites. Naturwissenschaften 86: 559-570.

4. Wilkins A. L. \& Elix J. A. (1990). New fernene triterpenes from the lichen Pseudocyphellaria aurata. Australian Journal of Chemistry 43: 623-7.

5. Wilkins A. L., Elix J. A., Gonzalez A. G., \& Perez C. (1989) A one- and two- dimesional ${ }^{1} \mathrm{H}$ and ${ }^{13} \mathrm{C}$ NMR study of some fernene triterpenoids. Australian Journal of Chemistry 42:1185-9.

6. Brassy C., Bachet B., Bodo B. \& Molho D. (1982). Structure de atranorine. Acta Crystallographica Section B 38: 3126-3128.

7. Solberg Y. J. (1987). Chemical constituents of the lichen species Cetraria delisei, Lobaria pulmonaria, Stereocaulon tomentosum and Usnea birta. Journal of the Hattori Botanical Laboratory 63: 357-366.
8. Norrestam R., Glehn M Von. \& Wachtmeiser C. A. (1974). Three-dimensional structure of usnic acid. Acta Chemica Scandinavica B 28: 1149-1152.

9. Nakanishi T., Yamauchi H., Fujiwara I. \& Tomitak K. (1971). The crystal structure of 6-O-bromobenzoylzeorin. Tetrabedron Letters 1157-1160.

10. Yosioka I., Nakanishi T., Yamauchi H. \& Kitagawa I. (1972a). Lichen triterpenoids. The final conclusion on the stereostructure of zeorin and its correlation with leucotylin. Chemical \& Pharmaceutical Bulletin 20: 147-156.

11. Tsuda Y., Nakajima S., Udayawa S-I. \& Uzawa J. (1980). The isolation from Myrothecium species and long-range selective proton decoupling ${ }^{13} \mathrm{C}$ NMR of rhizonic acid. Journal of Natural Products 43: 467-471.

12. Caccamese S., Compagnini A., Toscano R. M. \& Cascio O. (1986). Methyl- $\beta$-orcinolcarboxylate and atranol from the lichen Stereocaulon vesuvianum. Joumal of Natural Products 49: 11591160.

13. Bandara K. A. N. P., Kumar V., Jacobsson U. \& Molleyres L. P. (2000). Insecticidal piperidine alkaloid from Microcos paniculata stem bark. Phytochemistry 54:29-32.

14. De Silva K. W. D. S. (2001). Chemical investigation and biological activity of Glyricidia sepium. M.Phil. Thesis, University of Peradeniya, Peradeniya.

15. Leuckert C. \& Kümmerling H. (1991). Chemotaxonomischestudien in der gattung Leproloma Nyl. ex Crombie (Lichenes). Nova Hedwigia 52: 17-32.

16. Orange A., Wolseley P., Kanunaratne V. \& Bombuwela K. (2001). Two leprarioid lichens new to Sri Lanka. Bibliotheca Lichenologica 78: 327-33.

17. KarunaratneV., Bombuwela K., Kathirgamanathar S., Kumar V., Karunaratne D. N., Ranawana K. B., Wijesundara D. S. A., Weerasooriya A. \& De Silva E. D. (2002). An association between the butterfly Talicada nyseus and the lichen Leproloma sipmanianum as evidenced from chemical studies. Current Science 83: 741-45.

18. Karunananda Bombuwala B. D. (2001). Isolation and bioactivity studies of lichen substances from Sri Lankan lichens. Ph.D. Thesis, University of Peradeniya, Peradeniya. 